\title{
The use of narrative research for the learning of group dynamics by professionals from Psychosocial Care Centers
}

\author{
Uso de narrativas para o aprendizado da tecnologia grupal por \\ profissionais de Centros de Atenção Psicossocial \\ Uso de narrativas para el aprendizaje de la tecnología grupal por parte \\ de los profesionales de Centros de Atención Psicosocial
}

How to cite this article:

Nunes FC, Farinha MG, Barbosa MA, Caixeta CC, Costa AP, Silva NS. The use of narrative research for the learning of group dynamics by professionals from Psychosocial Care Centers. Rev Esc Enferm USP. 2021;55:e03772. doi: https://doi.org/10.1590/S1980-220X2020010403722

\author{
Fernanda Costa Nunes ${ }^{1}$ \\ Marciana Gonçalves Farinha² \\ Maria Alves Barbosa ${ }^{3}$ \\ Camila Cardoso Caixeta ${ }^{3}$ \\ António Pedro Costa \\ Nathália dos Santos Silva ${ }^{3}$ \\ ${ }^{1}$ Universidade Federal de Goiás, Faculdade \\ de Medicina, Goiânia, GO, Brazil. \\ ${ }^{2}$ Universidade Federal de Uberlândia, Instituto \\ de Psicologia, Uberlândia, MG, Brazil. \\ ${ }^{3}$ Universidade Federal de Goiás, Faculdade \\ de Enfermagem, Goiânia, GO, Brazil. \\ ${ }^{4}$ Universidade de Aveiro, Departamento \\ de Educação e Psicologia, Centro de \\ Investigação Didática e Tecnologia na \\ Formação de Formadores, Aveiro, Portugal.
}

\begin{abstract}
Objective: To analyze the results of the use of narratives in group therapy for the qualification process of professionals in the Psychosocial Care Centers on the use of group dynamics. Method: This is an action research involving 21 workers from 11 Psychosocial Care Centers in the Brazilian Central-West region. For data collection, narratives written by the participants about their work practices with therapeutic groups and theoretical discussion based on in-person workshops were used. Data were subjected to narrative analysis with the support of qualitative analysis software. Results: The category "Concerns and Questioning" showed the workers' lack of knowledge regarding the concept of group and group dynamics, the group management challenges, and the discomfort with the frustrations experienced by the group. The category "Learning for Group Coordination" showed knowledge acquisition for group planning and functioning, and understanding of the role of the group coordinator for mental health care. Conclusion: Narrating the scenes of group care allowed participants to exercise critical reflexive thinking, recognize the theory of group dynamics, and develop skills to coordinate groups.
\end{abstract}

\section{DESCRIPTORS}

Mental Disorders; Mental Health Services; Group Processes; Professional Training; Psychiatric Nursing.

\author{
Corresponding author: \\ Fernanda Costa Nunes \\ Universidade Federal de Goiás, \\ Faculdade de Medicina \\ Av. T3 n.1011, Apto. 2202, Edifício \\ San Bernardo, Setor Bueno \\ CEP 74215-110 - Goiânia, GO, Brazil \\ ferdsom@gmail.com
}

Received: 04/02/2020

Approved: 11/18/2020 


\section{INTRODUCTION}

Psychosocial care in mental health takes place in different modalities of therapeutic encounters, in the numerous Psychosocial Care Network services, among which the Psychosocial Care Centers (Centros de Atenção Psicossocial - CAPS) are highlighted. CAPS are strategic services for assisting people with serious and persistent mental disorders and/or with problems arising from drug use ${ }^{(1)}$.

More than a service, CAPS is a space representing a new social, cultural, technical, political, and ideological practice that guides the production of outpatient care aiming at rehabilitation and social reintegration. Treatment is offered where people live and work, with the participation and involvement of the families and the community, all through interprofessional work with a multiprofessional team ${ }^{(1)}$.

The work in the CAPS is built on a daily basis, when questions arise in the face of the daily effort of workers, users, and family members, to build strategies to overcome the difficulties and constant tension, and meet the needs in this setting. It is live work, produced in action, mediated ${ }^{(2)}$ by care technologies that consider the impacts of the different forces, either social, economic and political ${ }^{(3)}$, influencing the individual's mental health.

Groups and workshops are group therapy modalities aimed at mental health care based on interaction, sharing of experiences, and the provision of several experience activities, both carried out by one or two workers from the multiprofessional team ${ }^{(4-5)}$. The group technology aims to provide job integration to CAPS's users, and to involve them in artistic and craft activities, as well as to give them access to verbal and non-verbal means of expression on varied topics, such as love relationships, friendships, work, sexuality, family, leisure, culture, and health ${ }^{(6)}$. It provides psychosocial intervention through the bond between professionals and users, in addition to favoring the monitoring of the participants' treatment progression $^{(6-8)}$.

Group technology is understood here as the use of theoretical and practical resources in the field of group dynamics in varied contexts, such as: health care, people management, teaching, and research ${ }^{(9)}$. It allows collective psychosocial interventions and the construction of participatory learning and research processes ${ }^{(10)}$.

To investigate and intervene in complex environments such as those of CAPS, strategies capable of apprehending
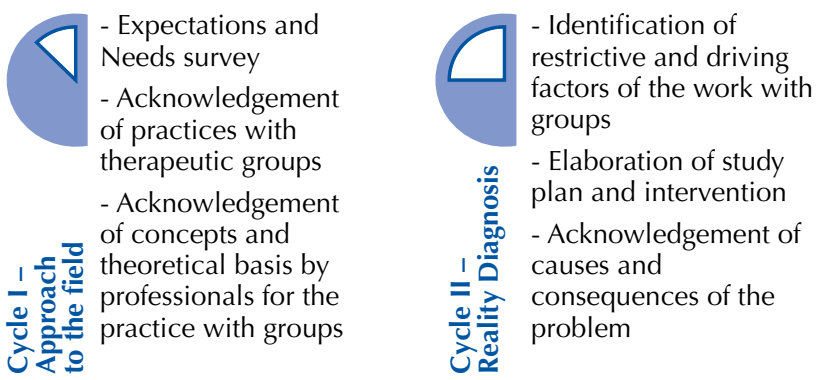

the varied facets of the operation of this service have to be chosen, and group practices are care technologies required to extrapolate the logic of individual consultation and to strengthen the psychosocial model. However, there is evidence that few professionals are trained and prepared to coordinate and conduct groups, workshops, and teams $s^{(9,11-12)}$.

Therefore, for the construction of this research, one opted for the use of group care narratives in CAPS. Narratives have been used as a powerful instrument for qualitative health research $^{(13)}$, as a strategy for continuing health education with group devices ${ }^{(14)}$, and as an influential resource in the process of health policy development ${ }^{(15)}$.

Accordingly, the objective of this study is to analyze the results of the use of narratives in group therapy for the qualification process of professionals in the CAPS on learning the use of group technology.

\section{METHOD}

\section{Design OF STUdY}

This article derives from the action research "Mental Health, Alcohol, and other Drugs and the Use of Group Technology", with a qualitative approach, whose object of work was the process of training mental health professionals who worked at $\mathrm{CAPS}^{(9)}$.

The epistemological perspective supporting and corroborating the action research addressed in this article is the complex paradigm, which states that complexity is in science and in everyday life ${ }^{(16)}$. The understanding that the teaching-learning and research practice that produces knowledge at work, with work, and for work is believed to be able to encourage the involvement and prominence of professionals in the collective construction of changes to improve health care services.

The study steps were organized into four distinct operational cycles, as shown in Figure 1, following two guiding principles of Morin's Theory of Complexity: the "retroactive loop principle" which states that the cause acts on the effect and the effect on the cause; and the "recursive loop principle" that defends the idea of self-production and self-organization ${ }^{(17)}$. The path of scientific practice chosen in the investigation was that of a collective act of construction, deconstruction, and self-construction that involved the researcher, participants, and elements of the researched setting.

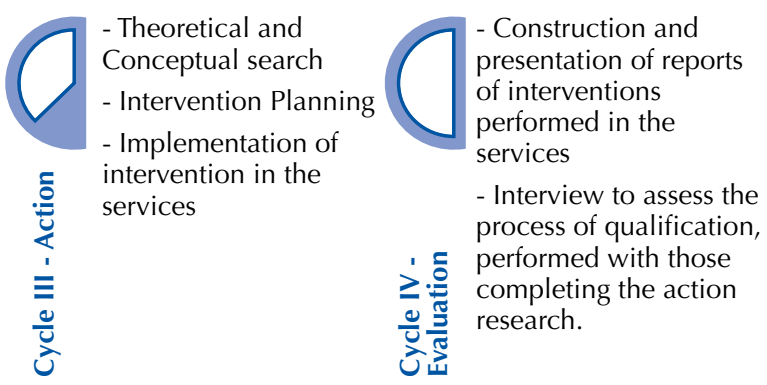

Figure 1 - Action Research Cycles "Mental Health, Alcohol, and Other Drugs and the Use of Group Technology". 


\section{Population}

Twenty-one workers from 11 Psychosocial Care Centers (CAPS) multiprofessional teams from different municipalities in a central-western Brazilian state participated in this study, with 4 CAPS I, 5 CAPS II, 2 CAPS Alcohol and Drugs, and one worker from the State Management. There was no voluntary adherence by CAPS III and Child CAPS to participate in the research. CAPS type I and II included in the study also served users of alcohol and other drugs, as well as children and adolescents.

At the time of the study, there were 56 qualified CAPS. The units participating in the study should have the consent from the service coordinator and the municipality's health manager to participate. The coordinator of each CAPS suggested two professionals from their team to participate in the research. Thus, the inclusion criteria to participate in the study were: being a professional with a higher education degree from the technical staff of the service and working at the CAPS selected at the time of data collection; working as coordinator of therapeutic groups in the service; and having participated in all data collection cycles of the study. A convenience sample was selected based on the intentional choice of services and active professionals, and on the criterion of qualitative and social representativeness ${ }^{(18)}$.

\section{Data COlleCtion}

Data collection took place from February to September 2017 and the results presented in this article were collected in the third cycle of the research, which consisted of the action phase in which the participants made theoretical and conceptual searches, planning and implementing of interventions in the services as shown in Figure 1. To systematize data collection, workers were asked to report, in writing, their daily practice with therapeutic groups at CAPS, encouraged by the following questions: What did we do today in the group? What was positive? What can be improved? What generated doubts and anguish? All narratives produced by the participants were sent by e-mail to the research team, who analyzed them based on the criteria of clarity, coherence, and richness of details narrated. Eight narratives were selected and delivered to the participants, who, divided into six trios and a quartet, organized by service, analyzed the narratives in two workshops, with an interval of 15 days between them. It was advised that the theorizing exercise should occur through creative, innovative, and dynamic strategies, with 40 minutes for each subgroup. Each workshop lasted eight hours and the group's discussions were recorded in audios that were fully transcribed for analysis.

\section{DATA ANALIYSIS AND TREATMENT}

Narrative analysis was chosen to delimit the categories that emerged in the research ${ }^{(19)}$. The process was carried out using the software webQDA, which allowed the visualization, interconnection, and organization of data, thus allowing coding, the creation of categories, and questioning, through the following software features: search for the most frequent words, word cloud, text search, and matrices ${ }^{(20)}$.

\section{ETHICAL ASPECTS}

The study was approved by the Research Ethics Committee of the Universidade Federal de Goiás with Report no. 3.951.500/20. It followed the provisions of Resolution 466/12, of the Brazilian Health Council, and all participants signed the Free and Informed Consent Form.

\section{RESULTS}

\section{PARTICIPANTS' SOCIODEMOGRAPHIC AND PROFESSIONAL PROFILE}

There were twenty female participants and one male in this study. Regarding the area of professional training, there were 09 psychologists, 05 social workers, 05 nurses, 01 occupational therapist, and 01 technician. The time of work in the field of mental health ranged from 1 year and 7 months to 9 years, according to Chart 1 .

Chart 1 - Participants' characterization in the study sample - Goiânia, GO, Brazil, 2019.

\begin{tabular}{|c|c|c|c|c|c|c|}
\hline City & Sex & Age & Training & Type of employment relationship & Time of service & Role at CAPS \\
\hline \multirow{2}{*}{ City 1} & Female & 34 & Social Worker & Temporary & 2 years & Technician \\
\hline & Female & 38 & Psychologist & Temporary & 6 years & Technician \\
\hline \multirow{2}{*}{ City 2} & Female & 53 & Psychologist & Temporary & 9 years & Coordinator \\
\hline & Male & 27 & Psychologist & Temporary & 2 years and 5 months & Coordinator \\
\hline \multirow{2}{*}{ City 3} & Female & 27 & Psychologist & Temporary & 1 year and 7 months & Technician \\
\hline & Female & 29 & Nurse & Temporary & 2 years & Technician \\
\hline \multirow{2}{*}{ City 4} & Female & 31 & Psychologist & Temporary & 4 years & Coordinator \\
\hline & Female & 38 & Psychologist & Temporary & 8 years & Technician \\
\hline City 5 & Female & 31 & Psychologist & Temporary & 5 years & Coordinator \\
\hline \multirow{2}{*}{ City 6} & Female & 30 & Nurse & Temporary & 3 years & Technician \\
\hline & Female & 35 & Social Worker & Civil servant & 8 years & Coordinator \\
\hline \multirow{4}{*}{ City 7} & Female & 43 & Social Worker & Temporary & 4 years & Coordinator \\
\hline & Female & 29 & Psychologist & Temporary & 4 years & Technician \\
\hline & Female & 52 & Social Worker & Civil servant & 3 years & Technician \\
\hline & Female & 30 & Nurse & Civil servant & 5 years and 9 months & Coordinator \\
\hline City 8 & Female & 28 & Nurse & Civil servant & 4 years & Technician \\
\hline \multirow{2}{*}{ City 9} & Female & 27 & Psychologist & Temporary & 2 years & Coordinator \\
\hline & Female & 37 & High School level & Temporary & 5 years & Technician \\
\hline \multirow{2}{*}{ City 10} & Female & 29 & Nurse & Civil servant & 2 years & Coordinator \\
\hline & Female & 33 & Occupational & Civil servant & 9 years & Technician \\
\hline State Management & Female & 69 & Social Worker & From another state & 9 years & Technician \\
\hline
\end{tabular}




\section{NARRATED SCENES ANALYSIS}

The narrated scenes analysis allowed viewing the dynamics of both groups and services surveyed. Data show that, in the CAPS surveyed, the therapeutic offerings are organized according to the demands of care, the diagnosis, and the users' age group. Therefore, the groups have rather varied objectives, among which the groups for embracement, psychoeducation, health education, and psychotherapy are highlighted.

The group narratives showed therapeutic meetings with different actors, plots, and scenarios, such as: adherence problems of the members of a group of adolescents in conflict with the law; meeting of CAPS's professionals for team development; silence and little involvement in the group of patients with mild mental disorder. Group formation involves the association of multiple therapeutic resources, such as theater, music, physical activity, conversation circles, group techniques and manual works, almost always used to attract and increase adherence of users and relatives.

The narratives show that, in many services, the groups are seen by a pair of professionals from different areas, indicating a multiprofessional work process of team-based care. Some scenes demonstrate that the user not always has clinical conditions or wishes to participate in the activities proposed in the therapeutic groups.

The main strategy for evaluating the groups' therapeutic results encompasses attendance at meetings, self-exposure behaviors, sharing of experiences, mutual help initiatives among group members, and adherence to the activities proposed in the group.

Two of the eight scenes worked on show team meetings with CAPS's professionals, and are used as team management strategy, space for interaction, continuing training, and embracement of workers' distresses.

Five scenes studied have adult users with mental disorders as leading figures. Of these, four scenes are with patients with varied severe pathologies (depression, schizophrenia, and bipolar disorder) and one scene with patients with mild disorders. There is only one scene with teenagers, none mentioning care of children or families.

\section{ReCOGNIZING CAPS'S PROFESSIONALS' LEARNING}

Chart 2 shows the central categories of the study, with the subcategories and the number of coded references. Fragments of the participants' statements are presented, here named as References, to help text comprehension. The references presented were identified with the word Participants and the number representing them in the study sample.

Chart 2 - Categories of analysis of the lessons learned with the study of group therapy narratives - Goiânia, GO, Brazil, 2019.

\begin{tabular}{|l|l|c|c|}
\hline Categories & Subcategories & Refs. & Source \\
\hline \multirow{4}{*}{$\begin{array}{l}\text { Concerns and } \\
\text { questioning }\end{array}$} & Doubts about the therapeutic objective & 13 & 2 \\
\cline { 2 - 4 } & Frustration of expectations & 17 & 2 \\
\cline { 2 - 4 } & Group management challenges & 16 & 2 \\
\cline { 2 - 4 } & Lack of knowledge about concepts & 6 & 2 \\
\hline \multirow{3}{*}{$\begin{array}{l}\text { Learning } \\
\text { for group } \\
\text { coordination }\end{array}$} & Understanding group functioning & 39 & 2 \\
\cline { 2 - 4 } & Role of the group coordinator & 19 & 2 \\
\cline { 2 - 4 } & Group Dynamics & 18 & 2 \\
\cline { 2 - 4 } & Group planning & 22 & 2 \\
\hline
\end{tabular}

\section{ConCERNS AND QUESTIONING}

Frustration in situations when the group did not function as desired, namely, occasions when the applied techniques did not lead to the expected outcome, was the situation most frequently reported in this category:

Because I foresaw a different result, and how I would manage it, because it wouldn't be the way it should be, or the way I thought it should be... and she guided me, thinking exactly about this approach of applying what we were experiencing, and not going against the specific demand of that group (Participant 19 - Ref.1 - Subcategory 'Frustration of expectations').

The workers also expressed discomfort in the face of the users' frequent behavior of only complaining about their symptoms during the groups meetings:

... We have a lot of difficulty in the groups, if nothing else, I have this CAPS where the patients want to come and bare their soul, they want to come and talk, they are feeling that, I am not sleeping, this week I felt such, such symptom, want to talk because they are feeling that week, they let off the steam (Participant 5 - Ref.4 - Subcategory 'Group management challenges').

Professionals' anguish when handling challenging situations during the coordination of therapeutic groups appeared in the difficulty of controlling time in view of the participants' need to talk:

... she says that she left something to be desired when she had to listen to a speech. I think everyone is concerned with this time issue, it happens too much, that speech happens a lot in our service too (Participant 19 - Ref.4 - Subcategory 'Group management challenges').

Participants also talked about the criteria for organizing and creating groups based on the pathology or on the users' life demands:

I have a question here, when we separate neurotics from psychotics, for example, are we segregating or are we doing clinical management? I have this doubt at CAPS, because we have this issue (Participant 7 - Ref.1 - Subcategory 'Doubts about the therapeutic objective').

The workers talked about the challenge of promoting adherence of the participants and family members in the groups, especially among the adolescent public:

We had an agreement with them, we asked them what they would like to do, how they would participate in it, and even then we are not being able to make the group go on (Participant 10 - Ref.2 - Subcategory 'Group management challenges').

Doubts arose about what the groups' therapeutic objectives would be, as well as their alignment with the users' demands:

Sometimes you ask what the purpose of our group is, and then I get confused, then I always report the objective of the group, but I want to know, the so-and-so group has a profile, a name, and this group works on that, because I don't associate, you know, these things (Participant 19 - Ref.1 - Subcategory 'Doubts about the therapeutic objective').

The group's lack of knowledge about concepts concerning three points of theorization showed to be a potential field for 
future learning investments, namely: 1) Analysis of the Group Field to recognize the driving and restrictive factors of the group:

The issue of restrictive factors, we looked for this term, restrictive factors. Then we even tried, took a text from the coordinator's role and then I told her, it's all that the coordinator has to do, but just the other way around... Is that right? (Participant 7 Ref.2 - Subcategory 'Lack of knowledge about concepts');

The role of the group co-coordinator:

I had doubts like that because I haven't found anything talking specifically about co-coordination, I don't know if it exists (Participant 9 - Ref. 2 - Subcategory 'Lack of knowledge about concepts');
And the conduction of the Experiential Learning Cycle (Ciclo da Aprendizagem Vivencial-CAV):

Look, can we tell the truth? We were in doubt about one thing of theory, for the $C A V$, does the person have to follow all steps of the process, is there a fixed order? (Participant 8 - Ref.3 Subcategory 'Lack of knowledge about concepts').

In view of the heterogeneity of the group of participants in this study, the following question arose: has the worker's professional category influenced in the type of questions raised and anguish experienced by them in the theorizing process? To answer this question, the Matrix tool of the software webQDA was used to construct questioning, as shown in Chart 3.

Chart 3 - Analysis matrix: "Professional category x Questioning and concerns" - Goiânia, GO, Brazil, 2019.

\begin{tabular}{|l|c|c|c|c|}
\hline Professional category & $\begin{array}{c}\text { Doubts about the } \\
\text { therapeutic objective }\end{array}$ & Frustration of expectations & $\begin{array}{c}\text { Group management } \\
\text { challenges }\end{array}$ & 3 \\
\hline Nurse & 0 & 6 & 8 & 7 \\
\hline Psychologist & 4 & 2 & 8 & 1 \\
\hline Social Worker & 0 & 1 & 1 & 1 \\
\hline Occupational Therapist & 4 & & 1 \\
\hline
\end{tabular}

The professionals stated that they alternated their role in the group, as coordinators or co-coordinators, and only one nurse mentioned always acting as coordinator of the groups. Nevertheless, the reports by psychologists were more frequent in all subcategories of the "questioning and concerns" nucleus. First comes their perception of the feeling of frustration from workers in the coordination of the groups; second, the reports about the challenges to the users' grouping criteria; third, questions about the need of having a co-coordinator in the therapeutic groups.

The matrix analysis allowed showing a possible relationship between the context units of the subcategories "group management challenges" and "frustration of expectations". It is noted that when group management is difficult, with negative and far from expected results, the feeling of frustration emerges in the group coordinator's experience.

\section{LEARNING FOR GROUP COORDINATION}

Despite the doubts and distresses, the study of narratives brought professionals a valuable exercise of learning and knowledge production. The problematization raised during the meetings allowed workers to understand that each group has a unique and singular reality that determines its functioning:

So you will have to adapt what you are applying, what you are applying to your reality; many times you will have to make some adjustments, because the group to which I provide that service there is not the same as here; just to start, there we have a group of users, here it is the group of service professionals, so this already shows that the group is different, the demands will be different (Participant 4 - Ref.3 - Subcategory 'Understanding group functioning').

The workers realized that the demand of the group and its members is sovereign to the demands of the coordinator, and that is why it is necessary to be attentive and open to the needs of the users who are in the therapeutic groups. They concluded that, in view of such aspects, anticipation and control of outcomes taking place in group meetings are unlikely:
So we have to be open for the users to bring their speech, their contribution, and we will not be prepared for all the situations that may arise (Participant 10 - Ref.12 - Subcategory 'Understanding group functioning').

To understand the role of the Group Coordinator, the research participants sought support in several theoretical approaches in psychology, among which the following stand out: the psychoanalytic, the psychodramatic, the gestalt, and the person-centered. The workers presented, by reading a fragment of the text "A look at the dynamics of the group coordinator" ${ }^{(21)}$, two major axes of competence that shall be mastered by the group coordinator, as shown in the following fragment:

The coordinator needs technical competence, which is the mastery of scientific concepts in the area and of the instruments applied, and interpersonal competence to lead the group spontaneously, providing an environment conducive to group integration (Participant 16 - Ref. 3 - Subcategory 'Role of the group coordinator').

The incursion of research participants in the theoretical field of Group Dynamics showed a process of (ac) knowledge(ment) of new concepts, such as: communication, leadership, group planning and organization, motivation, resistance, proper application of techniques and group experiences, and ethical responsibility with the group:

So for me, wow, this issue of groups is clear now, the objectives of the groups, the criteria, the planning, so this is very clear to me now, I've always suffered a lot, since the beginning of this course, I wanted more theory to understand how groups are formed (Participant 3 - Ref.21 - 'Subcategory Group planning').

One sought to understand if there was a significant difference in the knowledge discussed by the participants due to the variation of the professional categories, using the creation of the analysis matrix in webQDA for this purpose, as can be seen in Chart 4: 
Chart 4 - Analysis matrix: Knowledge discussed by participants by professional category - Goiânia, GO, Brazil, 2019.

\begin{tabular}{|l|c|c|c|c|}
\hline Matrix (E) & Group planning & $\begin{array}{c}\text { Understanding group } \\
\text { functioning }\end{array}$ & $\begin{array}{c}\text { Role of the group } \\
\text { coordinator }\end{array}$ & Group Dynamics Theory \\
\hline Psychologist & 9 & 17 & 9 & 3 \\
\hline Nurse & 8 & 10 & 6 & 9 \\
\hline Social Worker & 7 & 3 & 4 & 4 \\
\hline Occupational Therapist & 8 & 2 & 0 & 0 \\
\hline
\end{tabular}

Regarding group planning, knowledge seems to be aligned among the categories, with little variation in both the number of references and the quality. However, regarding the understanding of group functioning, the category of psychologists showed greater expressiveness in the number of references than all the others.

\section{DISCUSSION}

The group's offers identified in the narratives, as well as the associated use of multiple therapeutic resources to carry out the groups and promote the service users' adherence ${ }^{(23)}$, are consistent with the national guidelines for the functioning of CAPS ${ }^{(22)}$ and with the modality of groups discussed in the international literature.

The workers' theoretical incursions for the study of the scenes led them to understand that the objective of the therapeutic group is linked to its main focus, which can be: the prevention of relapses, the training of daily activities for autonomy, psychoeducation or health education, to name just a few examples. However, considering that every therapeutic group has goals of socialization, provision of support and learning, it will often have more than one simultaneous classification ${ }^{(24)}$.

The non-adherence of users to group activities appears in the results as a frequent and intense challenge for CAPS's professionals. This group phenomenon can have several meanings: resistance, lack of motivation for the task, activities that do not meet the users' demands and needs, or even incapacity to what was proposed in the group, due to the cognitive and/or relational limitations of the services users. It is noteworthy that the group functions as a complete and integrated system where each of its members is an important subsystem ${ }^{(8)}$. Thus, resistance or difficulties that seem to be individual or isolated can have repercussions in the entire group field. Therefore, it is necessary to be aware of the fact that non-adherence to treatment may occur due to the users' beliefs, values, and preferences, as in the group they influence each other and therefore change the group functioning dynamics ${ }^{(25)}$.

The scenes narrated show that the groups take place with double coordination in the services surveyed; however, it was evidenced that many workers are unaware of the concept of co-coordination and, consequently, do not realize the full therapeutic potential of this figure in the group. The cocoordinator or co-therapist is the one who observes and synthesizes the content of the group to support and complement the coordinator's readings and interpretations ${ }^{(26)}$. In situations of crisis in the group, the co-coordinator has the task of embracing the most mobilized users, while the coordinator continues with the conduction and closing of activities ${ }^{(21)}$.

As for the therapeutic results of the group, it is noteworthy that, in the scenes narrated, as well as in the discussions that followed, priority was given to strategies for checking the group process and the relational patterns characterizing it. There is no evidence on the use of efficacy assessment to compare health conditions, quality of life, or remission of symptoms, as international studies ${ }^{(27)}$ often report.

The references content in the "Learning for group coordination" showed, in the subcategory "Group Planning", workers' great concern with the proper application of group techniques to achieve a certain outcome or result. It is inferred that, due to the lack of theoretical and conceptual familiarity of the professionals with the Group Dynamics, they show great attachment to the scripts for carrying out activities as if they were a recipe or a linear and strict stepby-step guide to be followed. This mechanical action is often a mere strategy to fulfill the users' idle time or the professionals' agenda, without considering the group as a technology for transformation.

Apparently, the dynamic but unpredictable nature of the therapeutic groups generated in workers the perception of challenge in group management, the feeling of frustration and the lack of clarity of the therapeutic goals and objectives of the group. The literature points out that the greater the theoretical and technical mastery the group coordinator has over group processes and phenomena, the less they will be concerned with pre-defined paths for the group, and the greater will be their respect and tolerance to accept the contents and movements of the group dynamics, whether related to the disease and its symptoms, to the group itself or to the institution ${ }^{(21)}$.

Participants reported that understanding the concept of Group Dynamics as a movement resulting from the set of interactions within a psychosocial space, singular and specific to each one because it is produced by itself ${ }^{(28)}$ helped them to differentiate what is domain and characteristic typical of the group's activities, and what is the coordinator's responsibility. Distinguishing the attributions of each element of the Group Field ${ }^{(29)}$ is necessary for the construction of more efficient ways of offering psychosocial group therapy.

The production and study of group therapy narratives were used by the research team both as pedagogical devices for professional qualification and as a methodological resource for collecting qualitative data. When speaking, writing, and reading about their therapeutic groups, workers invariably thought and reflected on themselves and their 
professional practice, as the activity of writing is associated with the exercise of thinking in two different ways, a linear one, ranging from the work of reflection to the work of description of reality, and a circular one, as the reflection generates writing, and text re-reading leads to new reflections ${ }^{(30)}$.

It is understood that the registration of group therapy scenes has become a tool for the reconstruction of reality, because they were the target of critical analysis by those who produced them in association with the theories and concepts of Group Dynamics underlying the practice of therapeutic groups as care technology. In-service learning initiatives that enhance doing, creating, and transforming professional practice from the practice itself are more effective in responding to service demands, favoring multiprofessional work ${ }^{(9)}$.

The analysis of matrices generated with the software webQda shows psychology professionals more familiar with the content learned. This can be explained by the fact that "coordinating and managing group processes, considering the individual and socio-cultural differences of its members, the group demands, and the promotion of group autonomy and self-management" is part of the core of the competencies provided for in the curricular guidelines for undergraduate courses in Psychology ${ }^{(31)}$. In addition, the behavioral understanding of Group Dynamics is based on the main theoretical currents of psychology, namely: Psychoanalysis, Psychodrama and Gestalt ${ }^{(32)}$. However, the competence of other professionals for conducting groups is questioned, as there are group disciplines in the training of social workers, occupational therapists, and in the graduate courses in different areas. Therefore, Permanent Education in Health is important for the process of learning and developing skills in the service, with the service, and for the service.
Despite this, the other workers who participated in the study did not express inaptitude or lack of interest in learning Group Dynamics; on the contrary, they acknowledged how much they knew and confirmed successful practices acquired with the great experience time they had upon working with CAPS. Experience can also lead to competence, especially when supported by theory.

\section{CONCLUSION}

The results produced with the research and qualification strategy adopted show that narrating the scenes of group care, in writing, allowed the participants to exercise critical thinking through recognition and reflective description of the concrete reality of the work. The moment of studying the narratives brought to the participants the recognition of the vast existing literature on the field of Group Dynamics, the importance of adequate Group Planning, as well as the understanding of the knowledge, skills, and attitudes required for group coordination. When one introduces education at work, to some extent one assumes the insertion of transformation processes, that is, the introduction of changes through training.

Multidisciplinary teams can enrich group work at CAPS due to the diversity of therapeutic delivery and the views of various centers of expertise on the same phenomenon, which allows comprehensive and expanded care. It can be observed that Permanent Education in Health is important in favoring new learning, development, and improvement of skills of the professionals working in these services. This continuing education can contribute to adherence and participation in the groups and in activities proposed by these professionals.

\section{RESUMO}

Objetivo: Analisar os resultados sobre o uso de narrativas de cuidado grupal no processo de qualificação dos profissionais dos Centros de Atenção Psicossocial para o aprendizado do uso da tecnologia grupal. Método: Pesquisa-ação envolvendo 21 trabalhadores de 11 Centros de Atenção Psicossocial do Centro-Oeste brasileiro. Para coleta de dados foram utilizadas narrativas escritas pelos participantes sobre suas práticas de trabalho com grupos terapêuticos e oficinas presenciais para discussão teórica a partir das mesmas. Os dados foram submetidos à análise de narrativas com o suporte do software de análise qualitativa. Resultados: A categoria "Angústias e Questionamentos" evidenciou o desconhecimento dos trabalhadores quanto à conceituação de grupo e dinâmica de grupo, os desafios do manejo grupal e o desconforto com as frustrações vividas no grupo. A categoria "Aprendizados para Coordenação de Grupo" revelou aquisição de conhecimento para o planejamento e funcionamento grupal, e compreensão do papel de coordenador de grupos para o cuidado em saúde mental. Conclusão: Narrar as cenas de cuidado grupal possibilitou aos participantes exercitar o pensamento crítico reflexivo, reconhecer a teoria da tecnologia grupal e desenvolver habilidades para coordenar grupos.

\section{DESCRITORES}

Transtornos Mentais; Serviços de Saúde Mental; Processos Grupais; Capacitação Profissional; Enfermagem Psiquiátrica.

\section{RESUMEN}

Objetivo: Analizar los resultados sobre el uso de narrativas de atención grupal en el proceso de cualificación de los profesionales de los Centros de Atención Psicosocial para el aprendizaje del uso de la tecnología grupal. Método: Investigación-acción realizada con 21 trabajadores de 11 Centros de Atención Psicosocial ubicados en la región centro occidental de Brasil. Los datos se recogieron mediante narrativas escritas por los participantes acerca de sus prácticas de trabajo con grupos terapéuticos y talleres presenciales de discusión teórica basados en ellas. Estos datos se sometieron a un análisis narrativo con el apoyo de un software de análisis cualitativo. Resultados: La categoría "Angustias y Cuestionamientos" evidenció el desconocimiento de los trabajadores con respecto a la conceptualización de grupo y de dinámica de grupo; los desafíos de la gestión de grupo y la incomodidad con las frustraciones vividas en el grupo. La categoría "Aprendizajes para la Coordinación de Grupos" reveló la adquisición de conocimientos para la planificación y el funcionamiento del grupo, y la comprensión del papel de coordinador de grupos para la atención a la salud mental. Conclusión: La narración de las escenas de atención grupal les posibilitó a los participantes ejercitar el pensamiento crítico reflexivo, reconocer la teoría de la tecnología grupal y desarrollar habilidades para coordinar grupos.

\section{DESCRIPTORES}

Trastornos Mentales; Servicios de Salud Mental; Procesos de Grupo; Capacitación Profesional; Enfermería Psiquiátrica. 


\section{REFERENCES}

1. Amarante P, Nunes MO. Psychiatric reform in the SUS and the struggle for a society withou asylums. Cien Saude Colet. 2018;23:2067-74. doi: https://doi.org/10.1590/1413-81232018236.07082018

2. Franco TB, Merhy EE. Cartografias do trabalho e cuidado em saúde. Rev Tempus Actas Saúde Cole. 2012; 6:151-63. doi: https://doi. org/10.18569/tempus.v6i2.1120

3. Burgess RA, Jain S, Petersen I, Lund C, Ann Burgess R, Jain S, et al. Social interventions: a new era for global mental health? Lancet Psychiatry. 2019;19:9-10. doi: http://dx.doi.org/10.1016/S2215-0366(19)30397-9

4. Brasil. Ministério da Saúde. Saúde mental no SUS: os Centros de Atenção Psicossocial [Internet]. Brasília; 2004 [citado 2020 nov. 25]. Disponível em: http://www.ccs.saude.gov.br/saude_mental/pdf/sm_sus.pdf

5. Rauter C. Oficinas para que? Uma proposta ético-estético-política para oficinas terapêuticas. In: Amarante P, editor. Ensaios: subjetividade, saúde mental, sociedade. Rio de Janeiro: Fiocruz; 2000. p. 267-77.

6. Souza LGS, Pinheiro LB. Oficinas terapêuticas em um Centro de Atenção Psicossocial-álcool e drogas. Aletheia [Internet]. 2012 [citado 2020 nov. 25];38:218-27. Disponível em: http://www.periodicos.ulbra.br/index.php/aletheia/article/view/3375

7. Farias ID, Thofehrn MB, Andrade APM, Carvalho LA, Fernandes HN, Porto AR. Therapeutic workshops as expressions of subjectivity. SMAD Rev Eletr Saúde Ment Álcool e Drog. 2016; 12:147. doi: http://dx.doi.org/10.11606/issn.1806-6976.v12i3p147-153.

8. Ferreira KF, Carvalho VCS. Oficinas terapêuticas: caminhos de saberes. Ver Fac Ciênc Med Sorocaba. 2018;20:82-5. doi: https://doi. org/10.23925/1984-4840.2018v20i2a5

9. Nunes FC, Caixeta CC, Pinho ES, Souza ACS, Barbosa MA. Group technology in psychosocial care: a dialogue beteen action research and permanent health education. Texto Contexto Enferm. 2019;28:e20180161. doi: https://doi.org/10.1590/1980-265x-tce-2018-0161

10. Nunes FC, Farinha MG, Valentim F, Barbosa MA, Rua M dos S. Group interventions and action research in health. Millenium. 2020;2:6571. doi: https://doi.org/10.29352/mill0211.07.00273

11. Pinho ES, Souza ACS, Elizabeth E. Working processes of professionals at Psychosocial Care Centers (CAPS): an integrative review. Ciênc Saúde Coletiva. 2018;23(1):141-52. doi: https://doi.org/10.1590/1413-81232018231.08332015

12. Santos RCA, Pessoa Junior JM, Miranda FAN. Psychosocial care network: adequacy of roles and functions performed by professionals. Rev Gaúcha Enferm. 2018;39:e57448. doi: https://doi.org/10.1590/1983-1447.2018.57448.

13. Castellanos MEP. The narrative in qualitative research in health. Ciênc Saúde Coletiva. 2014;19(4):1065-76. doi: https://doi. org/10.1590/1413-81232014194.12052013

14. Diniz DS, Sá MDC. The use of narratives and group device approach in education/continuing education of health professionals: a literature review. Interface - Comun Saúde, Educ. 2019; 23:e180217. DOI: https://doi.org/10.1590/Interface.180217

15. Fadlallah R, El-Jardali F, Nomier M, Hemadi N, Arif K, Langlois EV, et al. Using narratives to impact health policy-making: a systematic review. Public Health Health Serv. 2019;17:1-22. doi: https://doi.org/10.1186/s12961-019-0423-4

16. Morin E. Introdução ao pensamento complexo. Porto Alegre: Editora Sulina; 2015.

17. Minayo MCS. Da inteligência parcial ao pensamento complexo: desafios da ciência e da sociedade contemporânea. Política Soc. 2011;10:41-6. doi: https://doi.org/10.5007/2175-7984.2011v10n19p41

18. Thiollent M. Metodologia da pesquisa-ação. São Paulo: Cortez; 2011.

19. Lindsay GM, Schwind JK. Narrative Inquiry: experience matters. Can J Nurs Res. 2016;48:14-20. doi: https://doi. org/10.1177/0844562116652230

20. Costa AP, Amado J. Análise de conteúdo suportada por Software. Aveiro: Ludomedia; 2018.

21. Mota KAMB, Munari DB. Um olhar para a dinâmica do coordenador de grupos. Rev Eletr Enferm. 2006;8:150-61. doi: https://doi. org/10.5216/ree.v8i1.931

22. Brasil. Ministério da Saúde. Centros de Atenção Psicossocial e Unidades de Acolhimento como lugares da atenção psicossocial nos territórios: orientações para elaboração de projetos de construção, reforma e ampliação de CAPS e de UA [Internet]. Brasília; 2015 [citado 2020 maio 17]. Disponível em: http://bvsms.saude.gov.br/bvs/publicacoes/centros_atencao_psicossocial_unidades_acolhimento.pdf

23. Lorentzen S, Ruud T. Group therapy in public mental health services: approaches, patients and group therapists. J Psychiatr Ment Health Nurs. 2014;21:219-25. doi: https://doi.org/10.1111/jpm.12072.

24. Castilho A. A dinâmica do trabalho de grupo. Rio de Janeiro: Qualitmark; 2002.

25. Ribeiro JP. O conceito de resistência na psicoterapia grupo-analítica: repensando um caminho. Psicol Teor Pesq. 2007;23(n. esp):65-71. doi: https://doi.org/10.1590/S0102-37722007000500013

26. Yalom ID, Leszcz M. Psicoterapia de grupo: teoria e prática. Porto Alegre: Osório LC; 2006.

27. Bros I, Notó P, Bulbena A. Effectiveness of short-term dynamic group psychotherapy in primary care for patients with depressive symptoms. Clin Psychol Psychother. 2017;24:826-34. doi: https://doi.org/10.1002/cpp.2029.

28. Malhiot GB. Dinâmica e gênese dos grupos. Petrópolis: Vozes; 2013.

29. Frazão LM, Fukumitsu KO. Modalidades de intervenção clínica em Gestalt terapia. São Paulo: Summus; 2016.

30. Foucault M. O que é um autor? Lisboa: Passagens; 1992. A escrita de si; p. 129-60. 
31. Brasil. Conselho Nacional de Saúde. Resolução 597, de 13 de setembro de 2018. Aprovar o parecer técnico que dispõe sobre as recomendações do Conselho Nacional de Saúde à proposta de Diretrizes Curriculares Nacionais do curso de graduação em Psicologia [Internet]. Brasil; 2018. [citado 2020 maio 17]. Disponível em: http://conselho.saude.gov.br/resolucoes/2018/Reso597.pdf

32. Mota KAMB, Leal ML. O processo de aprendizagem no modelo de educação de laboratório vivencial. In: Mota KAMB, Munari DB, editors. As trilhas do trabalho de grupos. Curitiba: CRV; 2016. p. 15-22. 